\title{
The Victorian city and the Christian imagination: from gothic city to garden city
}

Frances Knight

University of Nottingham

\begin{abstract}
This article discusses some of the ways in which ideas about the city influenced the thinking of British Christians from 1840 to the early twentieth century. First, it explores nonconformist conceptions of the city, suggesting that, although the urban environment offered favourable circumstances for nonconformist growth, a desire to return to, or incorporate elements of, rural life was rarely far away. It explores why, when the garden city movement began, it found such fertile soil among Christian thinkers. Secondly, it considers some of the biblical paradigms that shaped late-Victorian thinking about the city. Preachers and writers moved seamlessly from their well-stocked religious imaginations to contemplating the practicalities of the city, and back again. It is argued that the Christian evocation of medieval cities, biblical cities and garden cities shaped in important ways the conceptualisations of the urban world.
\end{abstract}

\section{Introduction}

This article investigates some of the ways in which ideas about the city influenced the thinking of Christians from 1840 to the early years of the twentieth century. It has two points of focus. First, it explores nonconformist conceptions of the city, arguing that, although the urban environment offered the most favourable circumstances for nonconformist growth, a desire to return to, or incorporate elements of, rural life was rarely far away. Although the evidence drawn upon is overwhelmingly from nonconformist sources, it is with Augustus Welby Pugin, the Roman Catholic with whom the nineteenth-century English gothic city is usually most closely identified, that the paper starts. The article explores why, when the garden city movement began at the end of the nineteenth century, it found such fertile soil among Christian thinkers. Secondly, it considers some of the biblical paradigms that shaped late-Victorian thinking about the city. The nonconformists discussed include the Congregationalists Robert Vaughan, R.W. Dale, J.B. Paton, W.T. Stead and Ebenezer Howard, the Baptist John Clifford and the Salvationist William Booth. Also included is an influential Anglican, Henry Scott Holland, who is relevant to this discussion because he was one of the earliest exponents of urban theology. ${ }^{1}$ As would be expected at this period, the

\footnotetext{
${ }^{1}$ H.S. Holland, Our Neighbours: A Handbook for the C.S.U. (London, 1911). For his determination to work with members of other religious groups on urban problems, see 61-2.
} 
Bible was being read with an increasing degree of sophistication. For the people discussed in this article, 'the city' could mean a tangible urban space, or it could signify a theological idea of community, or it could be a metaphor for the Church. These theological constructions were usually derived from biblical models, although they may have incorporated a nod towards Augustine's City of God and they were sometimes influenced by the subject's assimilation of the works of John Bunyan and William Blake. ${ }^{2}$ The people discussed tended to move seamlessly between their well-stocked religious imaginations, and the practicalities of the Victorian city. After some consideration of the historiographical context, the article begins in the nonconformist urban world. It will be argued that the imaginative evocation of medieval cities, biblical cities and garden cities - the latter the creation of Ebenezer Howard - shaped in important ways Victorian conceptualisations of the urban world.

Britain urbanised at an unprecedented rate during the late-eighteenth and nineteenth centuries, with such evident implications for the organisation and practice of religion that it is unsurprising that historians have shown a steady interest in studying the topic. The ways in which the churches attempted to respond to the challenge of rapid urban growth from the late-eighteenth to the mid-nineteenth centuries have been well documented, ${ }^{3}$ and so too has religion in the changing urban landscape of the late-nineteenth and early-twentieth centuries. Indeed, this later period has created particularly fertile ground for scholarship over several generations. In the 1970s, Hugh McLeod's pioneering study of religion in late-Victorian London allowed him to explore in great depth the correlations between social class and religious practice. ${ }^{4}$ Jeff Cox's work on Lambeth not only popularised the term 'diffusive Christianity' but also concentrated on the specifics of religious change without resorting to secularisation theory and had implications that extended well beyond South London. ${ }^{5}$ Sarah Williams expanded the horizon by studying religion in the neighbouring borough of Southwark, in a monograph that was very consciously not about the churches, but instead had

\footnotetext{
2 E. Bar-Yosef, The Holy Land in English Culture 1799-1917: Palestine and the Question of Orientalism (Oxford, 2005), 18-60.

${ }^{3}$ Major contributions include R.A. Soloway, Prelates and People: Ecclesiastical Social Thought in England 17831852 (London and Toronto, 1969); S.J. Brown, Thomas Chalmers and the Godly Commonwealth in Scotland (Oxford, 1982); A.M.C. Waterman, 'The Ideological Alliance of Political Economy and Christian Theology, 17981833' Journal of Ecclesiastical History, 34 (1983), 231-44; B. Hilton, The Age of Atonement: the influence of Evangelicalism on Social and Economic Thought 1785-1865 (Oxford, 1988); P. Mandler, 'Tories and Paupers: Christian Political Economy and the Making of the New Poor Law' The Historical Journal, 33 (1990), 85-125; M. Smith, Religion in Industrial Society: Oldham and Saddleworth 1740-1865 (Oxford, 1995).

${ }^{4} \mathrm{H}$. McLeod, Class and Religion in the Late Victorian City (London, 1974).

5 J. Cox, The English Churches in a Secular Society: Lambeth, 1870-1930 (Oxford, 1982).
} 
its focus on popular religion, and made use of oral history. ${ }^{6}$ Meanwhile, Jeremy Morris took the investigation a little further into the suburbs, with his study of the borough of Croydon, ${ }^{7}$ and Simon Green moved it to the north of England, with a focus on the West Riding of Yorkshire. ${ }^{8}$ Religion in nineteenth-century Scottish cities was discussed by Callum Brown. ${ }^{9}$ Many of these works stemmed from doctoral theses completed in the late-twentieth century. But as John Wolffe has noted recently 'since the turn of the millennium, however, this flow of work on British cities has almost dried up' ${ }^{10}$ Notable too is the relative paucity of work which focusses explicitly on the relationship between the country and the city, despite the fact that, as Raymond Williams reminded us, that relationship has been, and still is, for many millions of people a 'direct and intense preoccupation and experience. ${ }^{11}$ As the focus has moved away from urban case-studies, some new approaches have opened up. Their common feature is a focus on the way in which the city was conceptualised in the nineteenth-century imagination. Callum Brown began his influential work on The Death of Christian Britain with an exploration of the ways in which the clergy themselves intellectualised the discourse in which the 'heathen' city became a central tenet of nineteenth-century belief. ${ }^{12}$ He suggests, tellingly, that 'religious decline in Britain is intellectually located in the distance between two 'worlds': the pre-industrial and the industrial. ${ }^{13}$ In other words, where life in the countryside gave way to life in the town. Another interesting focus of some recent work has been the way in which nineteenth-century conceptions of biblical cities shaped and influenced the perception of the urban environment. Tristram Hunt's influential study does not merely reference Jerusalem in its title but returns to the metaphor at regular points in the text. Meanwhile, the team of authors assembled by David Gange and Michael Ledger-Lomas each contributed a chapter on their chosen biblical city, drawing out its meaning - whether in the

\footnotetext{
${ }^{6}$ S. Williams, Religious Belief and Popular Culture in Southwark c.1880-1939 (Oxford, 1999).

7 J. Morris, Religion and Urban Change: Croydon, 1840-1914 (Woodbridge, 1992).

${ }^{8}$ S.J.D Green, Religion in the Age of Decline: Organisation and Experience in Industrial Yorkshire 1870-1920 (Cambridge, 1996).

${ }^{9}$ C.G. Brown, Religion and Society in Scotland since 1707 (Edinburgh, 1997).

$10 \mathrm{~J}$. Wolffe, 'Towards the Post-Secular City? London since the 1960s' Journal of Religious History, 41 (2017), 535.

${ }^{11}$ R. Williams, The Country and the City (London, 1973), 3. See also A. Briggs, Cities and Countrysides: British and American Experience (1860-1914) (Leicester, 1982). The Ecclesiastical History Society tackled The Church in Town and Countryside as the theme for Studies in Church History 16, in 1979. It is evident, however, that most of the papers relating to the nineteenth century interpreted this as an opportunity to write about urban religion. The exceptions were the papers by G. Robson, D.W. Bebbington and D.M. Thompson.

${ }^{12}$ C.G. Brown, The Death of Christian Britain: Understanding Secularisation 1800-2000, second edition (Abingdon, 2009), 18-30.

13 Brown, Death, 16.
} 
form of moral warning, spiritual possibility, or both - for readers of the Bible in nineteenthcentury Britain. ${ }^{14}$

\section{The nonconformist city: from growing congregations to planting gardens}

One of the best-known visual depictions of the early Victorian city came from the pen of the Catholic convert, Augustus Welby Pugin. His contrasting pairings of 'Catholic Town in 1440 ' and 'the same town in 1840', which appeared in the second edition of Contrasts in 1841, illustrates the ways in which he saw Protestantism as having degraded the urban environment. ${ }^{15}$ The numerous church spires and other ecclesiastical buildings of 'Catholic Town' have been replaced by the gas works, iron works, gaol and lunatic asylum.

Furthermore, there are a multitude of competing Protestant nonconformist places of worship: the small print beneath the illustration refers to Mr Evans's chapel, the Baptist chapel, the Unitarian chapel, the Wesleyan Centenary chapel, the New Christian Society, the Quakers' Meeting - and, finally, the Socialist Hall of Science. ${ }^{16}$ Pugin elaborated further in his next publication, also in 1841, The True Principles of Pointed or Christian Architecture, in which he illustrated a plainly built parliamentary church, vying for space next to ugly warehouselike chapels, onto which classical facades had been crudely bolted, in an attempt to make them look impressive. 'Government preaching-houses, called churches, start up at the cost of a few hundred each, by the side of Zion chapels, Bethel Meetings, New Connexions, and Socialist Halls'. ${ }^{17}$ There was not a pointed arch in sight, and Pugin saw a slippery slope from the feeble wordiness of the Church of England, whose buildings were funded by government grants, to the confusing egalitarianism of dissenting meetings, whose buildings appeared to be supported by useless faux Grecian pillars. From there, he thought it was a short step to revolutionary socialism.

\footnotetext{
${ }^{14}$ T. Hunt, Building Jerusalem: The Rise and Fall of the Victorian City (London, 2004); D. Gange and M. LedgerLomas (eds.), Cities of God: The Bible and Archaeology in Nineteenth-Century Britain (Cambridge, 2013). See also Bar-Yosef, Holy Land and B. Quash, A. Rosen and C. Reddaway (eds.), Visualising a Sacred City: London, Art and Religion (London, 2017).

${ }^{15}$ A.W.N. Pugin, Contrasts: Or, A Parallel between the Noble Edifices of the Fourteenth and Fifteenth Centuries, and Similar Buildings of the Present Day; shewing the Present Decay of Taste: Accompanied by Appropriate Text second edition (London, 1841)

${ }^{16}$ Pugin, Contrasts plate 1.

17 Pugin, Principles of Pointed or Christian Architecture (London, 1841), 56.
} 
Pugin's vision of nonconformist places of worship jostling each other in the city was, however, an accurate one. The full scale of the religious diversity of mid-nineteenth century English towns would be revealed fifteen years later in the Religious Census of 1851, when 38 different Christian denominations, as well as Jewish worshippers, were identified. ${ }^{18}$ As country people poured into the towns (1851 was also the year when the majority of British citizens became town dwellers for the first time) they were faced with variety and choice in religious matters, in ways which they could barely have imagined in the countryside, together, of course, with greater invisibility which made practising no religion at all an easier option. Religious allegiances were not fixed. There is plenty of evidence of movement between the Church of England and nonconformity, and between different nonconformist chapels. The chapel records for Nottingham, a town in which about two thirds of worshippers were nonconformists during the nineteenth century, ${ }^{19}$ reveal the extent to which chapels added new members and deleted previous attenders who were now worshipping elsewhere. The chapel book of Broad Street General Baptist chapel, in the centre of the town, provides some examples: 'Mrs Goode - she having left off worshipping with us; and has been Baptised again, by some people calling themselves "Latter Day Saints"; 'James Goodson withdrawn - has not worshipped with us 2 or 3 years - has sat down and rec'd the ordinance of the Particular Baptists and principally attends with them'; 'Mary Stanger withdraws, having married an Independant' (sic); 'Sarah Cooper's name to be removed, she having joined the "New Testament Disciples"". ${ }^{20}$ This chapel recorded frequent movements and shifting denominational allegiances from the 1840s through to the 1870s, and in this respect appears typical of many urban congregations. ${ }^{21}$

Pugin had famously argued that gothic was the only style fit for ecclesiastical architecture, but if he had lived until the 1860s, he would presumably not have been pleased to see that

\footnotetext{
${ }^{18} \mathrm{H}$. Mann, (ed.) Census of Great Britain, 1851: Religious Worship in England and Wales (London, 1854), 106-7. For the Religious Census of 1851, see K.D.M. Snell and P.S. Ell, Rival Jerusalems: The Geography of Victorian Religion (Cambridge, 2000).

19 J. Beckett and B. H. Tolley, 'Church, chapel and school' in J. Becket (ed.) A Centenary History of Nottingham (Chichester, 2006) 364.

${ }^{20}$ These examples are taken from Broad Street General Baptist chapel book, and refer to Mary Goode (31 August, 1842), James Goodson (30 November 1842), Mary Stanger (2 October 1844) and Sarah Cooper (27 August, 1867). University of Nottingham Manuscripts and Special Collections, Mr M5/1 no foliation.

${ }^{21}$ Comments made by clergy and ministers in response to the 'average attendance' question in the 1851 Religious Census sometimes highlight this issue. For example, the incumbent of St Mary Magdalene's Lincoln wrote: 'Very uncertain. They go from church to church, from chapel to chapel and from church to chapel'. R.W. Ambler (ed.), Lincolnshire Returns of the Census of Religious Worship, 1851 (Lincoln, 1979), 109. On the general question of continuity in local patterns of religious adherence, see Snell and Ell, Rival Jerusalems.
} 
gothic revival churches had become so ubiquitous that they had ceased to be identified with Catholic theology. ${ }^{22}$ Many nonconformists were choosing gothic - at least for the exteriors of their new churches, as at Harrogate Congregationalist (1860-2) and Chapel Allerton Wesleyan Methodist (1871-6 - now demolished). There are numerous other examples, many still visible in English and Welsh towns and cities. Inside, of course, nonconformist theological principles were maintained, with the emphasis on the pulpit, not the altar. Under the influence of John Ruskin, and architects such as William Butterfield, George Gilbert Scott and their imitators, gothic revival had become synonymous with civic architecture. Indeed, it became so non-denominational and uncontroversial that it was adopted for Britain's first crematorium chapel, at Woking, which opened in $1885 .{ }^{23}$ Pugin would have been appalled, because cremation was regarded by Catholics as an 'atheistic' form of funeral until the 1960 s. $^{24}$

Growth in nonconformist influence was undoubtedly assisted by urbanisation. The number of chapels grew because there was a growing local population on which to draw. Furthermore, purchasing sites on which to build chapels was generally easier than in the Anglicandominated countryside. Growing numbers of nonconformists made it easier for them to wield political pressure, and sometimes to take direct action, seen in the campaigns against church rate in the 1830s and 1840s. Such campaigns could be damaging for the Church of England, as when the refusal to pay church rate for several years led to the closure of St Mary's in the centre of Nottingham in the early 1840s. ${ }^{25}$ But nonconformist politics was to move far beyond simply campaigning for religious equality. ${ }^{26}$ Nonconformist ministers took to municipal politics very readily: R.W. Dale, Birmingham Congregationalist and founder of the 'civic gospel', who was particularly active from the 1860 s to the 1880 s, was one of the most celebrated examples, although certainly not unique. ${ }^{27}$ Although disqualified as a

\footnotetext{
${ }^{22}$ S. Orchard, 'The free churches and their nation' in L. Husselbee and P. Ballard (eds.), Free Churches and Society: The Nonconformist Contribution to Social Welfare 1800-2010 (London, 2012), 19.

${ }^{23}$ F. Knight, 'Cremation and Christianity: English Anglican and Roman Catholic attitudes to cremation since 1885' Mortality 23 (2018), 301-309.

24 The change was part of the shifting mindset signalled by the Second Vatican Council. The Vatican issued Piam et constantem on 5 July 1963. Although earth burial was still seen as the preferred option, cremation was presented as an acceptable possibility. See Knight, 'Cremation and Christianity', 311-2.

${ }^{25}$ F. Knight, The Nineteenth-century Church and English Society (Cambridge, 1995), 72.

${ }^{26}$ T. Larsen, Friends of Religious Equality: Nonconformist Politics in Mid-Victorian England (Woodbridge, 1999).

${ }^{27}$ For Dale, see C. Gill, History of Birmingham I (Oxford, 1952) 378-9 and A. Briggs, History of Birmingham II (Oxford, 1952) 3, 68-9; Dale was one of the most prominent proponents of the civic gospel in Birmingham, but there were others of almost equal significance, notably George Dawson and Charles Vince. As Gill noted, 'There can be no doubt that the influence of religion was one of the strongest factors in creating that sense of
} 
minister of religion from election to Birmingham Town Council, Dale saw involvement in politics as a Christian imperative, and was a campaigner for improvements in gas and water supply, public parks and public buildings, better sewerage and free libraries. 'On the platform of the Town Hall the vigour with which he pulled off his overcoat as he rose to speak was a sure sign of what was coming; and when the meeting was tempestuous, as often happened when both political parties were present in force, he ploughed along through the storm with the steady rush of an Atlantic liner as it shoulders its way through blustering seas'. ${ }^{28}$ Dale would indefatigably just keep going with his municipal campaigns, night after night. He was rightly celebrated for his great contribution to the city of Birmingham, but his greatest influence was in persuading his fellow nonconformists that they too should become politically active. ${ }^{29}$

English cities became synonymous with religious liberty. It was, nonconformists believed, no coincidence that the Reformation had emerged in the German and Swiss city states. The earliest Victorian Christian apologists for urban life and values were unsurprisingly often nonconformists. Among the best known was the Congregationalist Professor of History at University College London Robert Vaughan, who published The Age of Great Cities: or, Modern Society viewed in its relations to Intelligence, Morals, and Religion in 1843.

Vaughan's aim was both to advocate for the greatness of great cities, whilst also defusing the objections of those 'who do not scruple to speak of great cities as the evil of the age' seeing them as places of 'ignorance, vice and irreligion'. ${ }^{30} \mathrm{He}$ adopted a vast canvas, beginning his defence of the city by extolling the virtues of the cities of the ancient world. There was, obviously, wretchedness and depravity to be found in the city, but he suggested that religious people often over-reacted to it, because they knew little of the conditions that had pertained in great cities in other times and lands. He was also quick to emphasise the extent of vice and depravity in the countryside. ${ }^{31}$ For Vaughan, the movement of people to cities was a marker of progress, with the Protestant cities of northern Europe facilitating the transmission of

civic pride and civic duty which was so conspicuous in Birmingham in the later years of the century. With these religious leaders loyalty to the City of God implied a corresponding loyalty to the earthly city'. (Gill, Birmingham 377).

${ }^{28}$ A.W.W. Dale, The Life of R.W. Dale of Birmingham (London, 1898), 404-5.

${ }^{29}$ D. M. Thompson, The emergence of the nonconformist social gospel in England in K. Robbins, (ed.) Protestant Evangelicalism: Britain, Ireland, Germany and America c. 1750-c.1850 (Oxford, 1990), 255-280.

${ }^{30}$ R. Vaughan, The Age of Great Cities: Or, Modern Society Viewed in its Relation to Intelligence, Morals and Religion (London, 1843), 5.

${ }^{31}$ Vaughan, Great Cities, 6, 239-49. 
Protestant values, such as education, industry and regular church-going. ${ }^{32} \mathrm{He}$ argued that in the Old Testament, urban life was a sign of progress: 'When the Almighty placed the Hebrew tribes in possession of the cities of Canaan, he recognised man as citizen, as an improvement upon man as a wanderer'. ${ }^{33}$ Vaughan read his Bible as a straightforward historical account. As Ledger-Lomas and Gange have noted, for Vaughan and for others of his generation, the 'relationship between the Bible and the modern city was symbiotic: the Bible shaped the understanding of urbanisation; city life coloured how the Bible was read'. ${ }^{34}$ It is significant that Vaughan resigned as president of the Lancashire Independent College in 1857, following a conflict with his colleague, the celebrated Old Testament scholar Samuel Davidson, who was forging ahead with scholarly study of the Hebrew scriptures. ${ }^{35}$

In the second half of the nineteenth century, nonconformist leaders took it for granted that their work would be more successful in the city. They were also worried that this would be at the expense of the villages, that had nurtured many of the dissenting causes which had been the cradle of their faith. An increasingly complicated relationship with the countryside, in which there was a growing sense of the potency of rural values, began to develop. ${ }^{36}$ Both the leading Baptist John Clifford, and the prominent Congregationalist J.B. Paton reflected this change. Speaking to Congregationalists gathered in Huddersfield in 1863, Paton concluded that 'It has been, and it is too much, the tendency of independent churches to ensconce themselves comfortably in thriving towns and well-to-do suburbs, and there to rejoice in a sort of Pharisaic respectability, heedless of the more destitute and difficult districts of the country. ${ }^{37}$ Addressing Baptists in Birmingham a decade later, Clifford lamented the loss of what he termed 'our obscure but heroic village Dissent', which had hitherto 'fed and nourished' the 'mighty forces of English Nonconformity'. He noted that nonconformist talent was draining from the countryside, as those who 'are most independent, most likely to think for themselves' were the ones who were also most likely to leave their villages and risk the

\footnotetext{
32 Vaughan, Great Cities, 77, 308.

${ }^{33}$ Vaughan, Great Cities, 103.

${ }^{34}$ Gange and Ledger-Lomas, Cities of God, 26.

$35 \mathrm{~J}$. Rogerson, 'Samuel Davidson and his dismissal in 1857' in J. Rogerson, Old Testament criticism in the nineteenth century: England and Germany (London, 1984) 197-208.

${ }^{36}$ D.W. Bebbington, 'The city, the countryside and the social gospel in late Victorian nonconformity' D. Baker (ed.) The Church in Town and Countryside: Studies in Church History 16 (Oxford, 1979), 415-426.

37 J.B. Paton, 'Evangelisation of Town and Country: a paper prepared for the annual assembly of the West Riding Congregational Union held in Huddersfield, 14 April 1863' (London, 1868), 20.
} 
hazards of emigration to Canada or Australia, or to try their luck in the crowded town. ${ }^{38}$ It was time for town-dwelling nonconformists to repay their debt to the countryside: Clifford's solution was for every town church to 'have its body of village preachers' going out to supply needy villagers with the benefits of their superior experience and intelligence. Town and village needed to align their interests, and towns needed to avoid internal competition and the useless proliferation of chapels. ${ }^{39}$ It was becoming clear that although nonconformity might appear to transplant easily to the urban world, the reality was that the roots could be shallow, and that what remained in the countryside might be too weak to thrive. Concern at the loss of talent, energy and entrepreneurship from the countryside would remain a constant theme in the decades that followed. ${ }^{40}$

By the late Victorian period it was becoming evident that nonconformity was weakening in the city centres. Chapels were particularly vulnerable to shifting patterns of residence, as upwardly-mobile members moved out of the city centres, and into the suburbs. ${ }^{41}$ People's perception, however, was of a constant flow from countryside to town, and this was confirmed by the decennial census figures: the census of 1901 recorded the percentage of urban population for England and Wales as 77 per cent. For Paton, citing this figure in 1905, and suggesting that it was probably now more like 80 per cent, the 'country regions of our land' were 'wide but almost empty'. ${ }^{42}$ This was not entirely true, of course, but in the forty years between 1851 and 1891, the agricultural population had decreased by one third. ${ }^{43}$ Paton's concern at this had led to him founding the English Land Colonisation Society in 1893, with the purpose of encouraging people back to the land to work small-holdings on a cooperative basis, bulk purchasing products and sharing equipment. His aim was to restore a race of sturdy English yeomen (a word he favoured) but the scheme encountered many of the same problems that beset similar projects at this date; unemployed city dwellers did not adjust easily to becoming rural small-holders. ${ }^{44}$ This led to him setting up a 268 acre training

\footnotetext{
38 J. Clifford, 'Religious Life in the Rural Districts of England: a paper read at the Baptist Union held at Birmingham, 2-5 October 1876' (London, 1876), 5-6.

${ }^{39}$ Clifford, 'Religious Life', 9-15.

${ }^{40}$ Countering this was one of the reasons offered in favour of the development of garden cities. See D. Bowie, The Radical and Socialist Tradition in British Planning: From Puritan colonies to garden cities (Abingdon, 2017), 179.

${ }^{41}$ P. Catterall, 'Slums and Salvation' in Husselbee and Ballard, Free Churches and Society, 119-20

42 J.B. Paton, Applied Christianity: A Civic League - Social and Educational - for our Towns and Cities (London, 1906), 18.

43 J.L. Paton, John Brown Paton: A Biography (London, 1914), 237

${ }^{44}$ Paton, Paton, 235-45.
} 
colony at Lingfield, in Surrey, but that too was short lived. Strongly inspired by the examples of his close friends, Dale in Birmingham and William Booth, Paton had greater success with city initiatives. He urged the formation of civic leagues, based on the German Elberfeld system, in which each city was divided into divisions and sub-districts, with large numbers of volunteers recruited to visit and assist specified needy individuals on a weekly basis. ${ }^{45}$

Paton expected each civic league to concern itself with the 'health and beauty' of the city, ensuring that new suburbs were planned with 'broad avenues adorned with trees and spacious recreation grounds, and breathing space around each house in gardens, where flowers and fruits may grow'. ${ }^{46}$ This, together with his plea for local authorities to engage in 'rational' planning 'before a sod is turned' reveals the extent to which he appears to have been influenced by the ideas of fellow Congregationalist, Ebenezer Howard, who was becoming famous for his advocacy of garden cities. Howard had selected his church, Rectory Road Congregational in Stoke Newington, as the venue in which to launch Tomorrow: A Peaceful Path to Real Reform, the book in which he set out these ideas, in $1898 .{ }^{47}$ They were put into practice remarkably quickly, and by 1905 , when Paton was addressing his audience in Manchester, the settlement known as First Garden City was being built at Letchworth, and already had two thousand residents, including Howard himself, and some other church members from Stoke Newington. The Garden City Association, the organisation which had made this possible, had a large membership, and included the active support of a number of wealthy nonconformist businessmen, including George Cadbury, Joseph Rowntree and William Hesketh Lever. ${ }^{48}$ Ebenezer Howard has long been celebrated as the innovator of the global garden city movement, but his religious motivations, although not entirely neglected in the existing literature, have tended to be downplayed. Yet, as his disciple and collaborator Frederic Osborn noted on several occasions, Howard was 'always thinking about religion' it was his 'third obsession' (together with garden cities and mechanical inventions). ${ }^{49}$ As a young man, Howard had been secretary to the celebrated Congregational minister Joseph Parker, and he retained a deep attachment to the progressive ideas of fin de siècle Congregationalism. But he was also powerfully influenced by Spiritualism, and like many of

\footnotetext{
${ }^{45}$ Paton, Paton, 468-78.

${ }^{46}$ Paton, Applied Christianity, 35.

47 The first edition of Howard's Tomorrow: A Peaceful Path to Real Reform appeared in 1898, and a second edition, with a slightly less radical sounding title, Garden Cities of Tomorrow was published in 1902.

${ }^{48}$ R. Beevers, The Garden City Utopia: A Critical Biography of Ebenezer Howard (Basingstoke, 1988), 79, 118.

${ }^{49}$ Hertfordshire Archives and Local Studies (HALS) DE/FJO/I1/2 Notes made by F. Osborn for a lecture in 1963.
} 
his generation, looked to Spiritualism to provide a scientific basis for belief in Christianity. He wanted his garden cities to be places of spiritual exploration and renewal, where the best of the rural and urban worlds would be held in harmonious balance. ${ }^{50}$

J.B. Paton, like many other ministers, was an early enthusiast of garden cities, ${ }^{51}$ but he did not follow Howard's radical line that existing cities should be more or less abandoned in favour of a completely fresh start in the countryside. Paton cited with approval the 'Country in Town' movement, which had been set up by the Anglican Samuel Barnett, and the appropriately-named horticulturalist Edward Owen Greening, to provide an alternative to the garden city movement, by advocating the mass planting of urban spaces. He outlined its principles:

To convert London into a Garden City we shall need not only to develop gardens of utility and beauty on all vacant available ground. We shall have to realise that every little forecourt and backyard is a possible garden, every flat roof can be used for garden purposes, every house-front can be adorned with graceful climbers, every verandah can be hung with flower baskets showering down beauty, every doorway and window is capable of floral adornment, almost every church, chapel, school, and public library can be draped with greenery grateful to the tired eyes of dwellers in London streets' ... Even in London, trees, flowers and abundant fruit are possible. ${ }^{52}$

Paton's intensely aesthetic vision emphasises how important the greening of the British urban environment was becoming by the turn of the twentieth century.

Barnett, who is best known as the founder of Toynbee Hall, claimed in an essay of 1893 that life in the city was the best preparation for life in the city of God. It was, however, a biblically-inspired vision which also contained elements of a perfected form of rural life: 'The prophets foresaw, not a paradise or a garden, but a city with its streets and its markets,

\footnotetext{
${ }^{50}$ In addition to Beevers, Garden City Utopia, on Howard, see F.J. Osborn, 'Sir Ebenezer Howard: the evolution of his ideas' The Town Planning Review 21 (1950), 221-235; R. Fishman, Urban Utopias in the Twentieth Century: Ebenezer Howard, Frank Lloyd Wright and Le Corbusier (New York, 1977); S. Buder, Visionaries and Planners: the Garden City Movement and the Modern Community (Oxford, 1990); S. Meacham, Regaining Paradise: Englishness and the Early Garden City Movement (New Haven, 1999).

${ }^{51}$ Paton preached one of his last sermons at the Free Church in Letchworth, in 1912. Paton, Paton, 500.

52 Paton, Applied Christianity 36.
} 
its manifold interests and its hum of life'. ${ }^{53}$ Then came the point now firmly embedded in the late-nineteenth century Christian mindset: 'its spaces will be many; great open spaces for games; small open spaces, within the reach of every house ... Trees and flowers will grow in the streets, along which will run streams of pure water'. ${ }^{54}$ It was but a short step from Barnett's re-imagined Bristol (his home city) to the Christian celebration of garden cities. A.S. Matheson, a Scottish Presbyterian minister, developed this theme, with his tellingly entitled volume, City of Man. Garden cities, he believed, offered the greatest potential for uniting all the competing human instincts. Matheson made the comparison between the garden city and the New Jerusalem of Revelation 21: 'Let us notice how the Garden City ideal possesses some of the features which belong to the ideal city of God described at the end of the Apocalypse. ${ }^{55}$ The garden city, he thought, signalled a return to the prelapsarian state that mankind had enjoyed in Eden: 'Man is meant to live amid the fair and happy aspects of creation, adding to the fertility and sweetness of the garden. ${ }^{56}$ But the advantages were practical, as well as theological: 'The benefits of town and country in one ... must be secured if we as a nation are to continue in the line of our past traditions. ${ }^{, 57}$

\section{After Babylon, Jerusalem and St Paul: biblical paradigms and the late Victorian city}

There is a better-known strand of nonconformist thought which conceptualised the city in far more negative terms. Through their writings on London, Andrew Mearns, W.T. Stead, Richard Mudie-Smith, Charles Booth and William Booth - who were all nonconformists of various denominations - together with the journalists on the nonconformist British Weekly contributed to a climate of anxiety about the dangers of the urban environment. They were fuelling the well-established narrative that Callum Brown has termed 'the myth of the unholy city'. ${ }^{58}$ A newer element in the perception of urban godlessness was the acknowledgement that the environment itself was inherently corrupting. This was an insight which had consequences for the understanding of sin, traditionally accounted for by Christians as an inevitable part of the human condition, that is as a consequence of the fallen nature of

\footnotetext{
${ }^{53}$ H.E. Meller, (ed.) The Ideal City: The Ideal City by Canon Barnett and Civics: as Applied Sociology by Patrick Geddes (Leicester, 1979), 55.

${ }^{54}$ Meller, Ideal City, 57, 58.

${ }^{55}$ A.S. Matheson, City of Man (London, 1910), 141.

${ }^{56}$ Matheson, City, 142.

57 Matheson, City 148. For a slightly longer discussion of Matheson, see F. Knight, Victorian Christianity at the Fin de Siècle: The Culture of English Religion in a Decadent Age (London, 2015), 199-200.

${ }^{58}$ Brown, Death, 18-30. Brown, of course, takes the view that the 'myth of the unholy city' was indeed a myth, in the sense of being false.
} 
humanity. But 'sin' in the late nineteenth century was in the process of re-definition. This was partly, as Dominic Erdozain has suggested, a shift to equating it with what had hitherto been seen as secular vices ${ }^{59}$ but perhaps more importantly, a shift towards seeing it as woven into society's unjust structures. It was widely agreed that people could not be made good by Acts of Parliament, but it was also readily acknowledged that legislation was urgently needed so that misery and exploitation became less likely. As Henry Scott Holland put it, 'No one, at this time of day, is going to decry the influence of Environment upon character ... He would condemn himself as an imbecile. The entire body of knowledge and experience emphasises, with ever increasing force, the power of Environment'. ${ }^{60}$

It was hardly surprising that Christian thinkers reached for readily understood biblical metaphors to explain London's predicament. 'The Maiden Tribute in Modern Babylon' screamed the headline in the Pall Mall Gazette, advertising W.T. Stead's series of articles in the summer of 1885, in which he exposed aspects of the London sex industry, and the ease with which very young girls could be prostituted. Although Stead readily adopted the 'social purity' language of his day, dividing girls into the categories of 'pure and innocent', and 'seduced and ruined', the fact that he could put the blame for the situation squarely on the seducers was an example of the way in which this shift in the understanding of sin was beginning to take hold. ${ }^{61}$ Stead's 'Maiden Tribute in Modern Babylon' headline mixed biblical and classical references. In the Greek myth of Hellas, seven youths and seven maidens were offered in tribute by Athens to Greece once in nine years, and were devoured by a minotaur - half man, half bull. Other biblically-sinful cities, particularly Sodom and Gomorrah, came in for unfavourable Victorian scrutiny, ${ }^{62}$ but it was Babylon which became a short-hand for urban sin and depravity. This was particularly true when applied to London, the city of great wealth, which seemed in danger of imminent moral collapse. ${ }^{63}$ The graphic depiction of the fall of Babylon in Revelation 18 provided plenty of allusions which could be deployed by writers and preachers who felt compelled to offer a warning to Victorian

\footnotetext{
59 D. Erdozain, 'The secularisation of sin in the nineteenth century' Journal of Ecclesiastical History 62 (2011) 59-88. 1851' Representations, 112, (2010) 1-26; H. Cocks, 'Sodom and Gomorrah, 14 January 1851'; Victorian Review 36 (2010) 27-30; M. Warner, 'New English Sodom' American Literature 64, (1992) 19-47.

${ }^{63}$ M. Seymour, 'Babylon' in Gange and Ledger-Lomas, Cities of God 171-8; L. Nead, Victorian Babylon: People, Streets and Images in Nineteenth-century London (New Haven and London, 2000).
} 
Londoners. If Babylon symbolised all that was worst in the city, the evocation of Jerusalem was its antithesis as a synonym for the sublime, perfected City of God. This was the 'New Jerusalem' that came down from heaven in John of Patmos's vision in Revelation 21, and was not to be confused with the unimpressive, grubby little middle eastern city that was being experienced at first hand by increasing numbers of Victorian tourists and pilgrims. ${ }^{64}$

Stead, although a Congregationalist, was closely associated with the Salvation Army, and was the ghost writer for William Booth's famous treatise on ending unemployment and poverty In Darkest England and the Way Out (1890). The text bears many of the hallmarks of Stead's sensation journalism, ${ }^{65}$ but better known than the text is the full colour fold-out plate which was attached as a frontispiece. It is headed 'Work for All: Salvation Army Social Campaign', with a note at the bottom explaining that 'The Chart is intended to give a birdseye-view of the Scheme described in this book, and the results expected by its realisation'. The viewer is presented with an immensely detailed scene. Whether the unknown artist was consciously incorporating elements from the Babylon/New Jerusalem imagery in Revelation is unclear, but he or she appears to have been influenced, perhaps subliminally, by the text. The sea-depicted as a raging ocean at the bottom of the picture and a tranquil waterway at the top (reminiscent of a sea of glass - as in Rev 4.6,15.2) frames the picture. In between, we see the activities of the city colony and the farm colony. At the base, amid lightning flashes and lost shipping, drowning souls are depicted disappearing under the waves of this churning sea of sin, (reminiscent of Rev 8.5 and 9). They are the victims of sweated labour, unemployment, drunkenness, misery, gambling and many other associated misfortunes. Members of the Salvation Army are plucking people from this ocean of despair. The picture is filled with people and statistics, a 'great multitude which no man could number' (Rev 8.9). There is a 'procession of the rescued'66 on their way to the city colony, where they will be given shelter and learn trade skills. Thirty-five practical schemes are depicted in the city colony, some of which existed at the time of the book's publication, all of which were planned. Moving up the picture, the farm colony comes into view, and 'another procession can be seen, of those who, having proved themselves worthy of further assistance ${ }^{67}$ are on their way there. This is not a romanticised view of the

\footnotetext{
${ }^{64} \mathrm{~S}$. Goldhill, 'Jerusalem' in Gange and Ledger-Lomas, Cities of God 71-110.

65 Knight, Victorian Christianity, 181-4.

66 'Work for All: Salvation Army Social Campaign' lithograph, (London, 1890). Quotations taken from the text at the bottom of the picture.

67 'Work for All'.
} 
countryside, or a garden paradise. It is an industrialising rural landscape for training in agricultural skills, dominated by the same redbrick institutional style of architecture that the artist depicts in the city, but it makes the point that the country is absolutely necessary in the scheme of salvation. Its greenness is the central point in the picture, where the viewer rests their eyes. The picture is framed by two prominent columns, around which are woven banners giving statistics for (among other things) the numbers of prostitutes, criminals, drink sales and suicides. This gives the image something of the appearance of a late-Victorian counterpart to a medieval doom painting. But it is also a map, a route from Babylon to Jerusalem, via work skills and emigration. As the eye moves further upwards, the focus is on the road and railway that lead to the embarkation point, where ships depart for the 'colonyover-sea yet to be established' ${ }^{68}$ which, like the New Jerusalem of Revelation 21, appears to be coming down from heaven. In this strange vision of salvation, London/ Babylon has become an enormous first aid post and training institution, in which the poor are rehabilitated and acquire training and skills for deployment in the New Jerusalem overseas.

Bruce Malina remarked that 'What we expect to find in [Revelation] depends entirely on the kind of writing we think it is. ${ }^{69}$ By the end of the Victorian period, it was increasingly being seen as a storehouse of metaphor, with the New Jerusalem appealed to as a complex rhetorical device. The following example comes from J.B. Paton:

We dream with longing of the New Jerusalem above, that we may enter there its pearly gates; but a nobler task has been given us. Behold the vision of the prophet: "Lo, I saw the New Jerusalem coming down to earth" to be builded here. Prepare, then, the way of the Lord, restore the waste places of this city fit to be the dwellingplace - the tabernacle of your God; for it is of this new city, which is not in heaven above, but which is coming down out of heaven to earth, and which is to be planted here in Manchester and Salford, that these words have been spoken. "Behold, the tabernacle of God is with men, and He will dwell with them". "And the glory of God doth lighten it, and the Lamb, in the shining of his love, "is the light thereof". ${ }^{70}$

\footnotetext{
68 'Work for All'.

${ }^{69}$ B.J. Malina, The New Jerusalem in the Revelation of John: The City as Symbol of Life with God (Collegeville, Minn., 2000), 3.

70 Paton, Applied Christianity, 48-9.
} 
This passage is a palimpsest of biblical allusions, mainly from Revelation 21 ('the New Jerusalem coming down to earth', the 'pearly gates', the 'tabernacle of God is with men, and He will dwell with them' and 'the Lamb ... is the light thereof') mixed with Mark 1:3 and Isaiah 40:3 ('prepare the way of the Lord') and Isaiah 58.12 (restore the waste places). Significantly, whereas in John's vision the New Jerusalem coming out of heaven is 'prepared as a bride adorned for her husband' (Rev 21.2) in Paton's vision it is 'builded here', a phrase which derives from William Blake's Jerusalem and is not found in the Bible. Blake's poem was frequently cited during this period, and Paton slips the archaic verb form in as if it were biblical language, to give a greater sense of authority to his argument that this is really something that concerns Manchester and Salford. As Revelation 21 is the penultimate chapter of the New Testament, he also uses it to signal to his audience that he was coming to his conclusion. Earlier in the same address, Paton had deployed biblical imagery for a different purpose, borrowing the language of St Paul (Rom 12:5; 1 Cor 12:12) in order to imagine the city in terms of renewed moral relationships. He told his audience that

Town and cities are no longer regarded as mere aggregates of units, jarring and warring with each other, but are seen to have a corporate life, in which each one somehow or other affects the life of the whole body, and the whole body is felt to have responsibility for the health and welfare of its members who are 'members one of another.' ${ }^{71}$

The same approach, mixing a New Testament theology of civic interconnectedness with the rhetorical power of imagery derived from the Revelation of St John, is found in the Anglican theologian Henry Scott Holland. In 1894, Holland delivered a series of four retreat talks on the 'City of God' to the clergy of the Welsh diocese of St Asaph. ${ }^{72}$ He began with a text from the Epistle to the Hebrews (Heb 12: 22-4), possibly chosen to offer encouragement to his audience, whom he could safely assume would feel beleaguered by the strength of Welsh nonconformity, and the prospect of the disestablishment of their Church. ${ }^{73}$ For his subsequent talks, he used two texts from Paul's letter to the Ephesians (Eph 2:19-22 and Eph 3:17-19) interspersed with a text from Revelation (Rev 19:1-6). The Ephesians texts were similarly

\footnotetext{
71 Paton, Applied Christianity, 16.

72 These were published as H.S. Holland, God's City and the Coming of the Kingdom (London, 1897).

73 The disestablishment of the Welsh Church was finally achieved in 1920, after a bitter nonconformist campaign which had lasted since 1870.
} 
positive, 'ye are no more strangers and foreigners, but fellow citizens with the saints...' The Revelation reading was a meditation on the praises in heaven, that were offered following the destruction of Babylon (Rome). Holland's addresses were heavily laced with 'city' language, usually as a metaphor for the Church, something which had an echo of Augustine's City of God. ${ }^{74}$ But for Holland it was rather different: the 'Heavenly City' signified the invisible Church, the 'City' the visible Church. Although he made some brief allusions to a Bunyanesque spiritual pilgrimage to the Heavenly Zion, he made it clear that he saw the most important direction of travel as the opposite way. 'Because of our ardour of faith in that Jerusalem on high, therefore we pour out our love upon the Jerusalem below ... the "Kingdom of Heaven" should not carry us from earth to heaven, but from heaven to earth. It starts out in heaven - it works out on earth. ${ }^{, 75}$

Even in rural Denbighshire, Holland's thoughts were never far from actual cities. St Paul, he suggested, was a dedicated urbanite. He had wanted to see Rome: today, he would have said, 'I, the Apostle of the City of God, must, at all costs, see Paris, and London, and Manchester and New York' ${ }^{76}$ Holland escaped from his biblical metaphors long enough to return his hearers periodically to the world of 1890s civic responsibility. For Holland, as for others, Christian citizenship in Jerusalem was simultaneously a spiritual and a practical reality. In 1896, he founded a monthly journal, The Commonwealth, which provided a platform from which he could unite his theological and political ideas. Commentary on the city remained much to the fore. In his first editorial, he wrote:

Nationalise yourself, your interest, your sympathies, your joys. Socialise yourself, out of sheer and free goodwill for the Common Weal. ... Everyone's sorrow is our sorrow, and all have a claim on our gladness ... This is the way the City is built: and it is time to set about building it in real earnest. That City rests on the fundamental conviction that no one of us can possibly live to himself alone, even if he wished it. ${ }^{77}$

This Christian socialist slipped from Heavenly cities to real cities, and back again, with remarkable ease. The fullest expression of Holland's urban theology came in his book of

\footnotetext{
${ }^{74}$ P. Brown, Augustine of Hippo: A Biography (London, 1967), 299-312. For Augustine, the two cities in The City of God were the heavenly realm of the City of God (the Church) and the earthly realm of the City of the World. ${ }^{75}$ Holland, God's City, 33, 36.

${ }^{76}$ Holland, God's City, 45.

77 The Commonwealth: A Social Magazine 1 (1896), 4.
} 
1911, Our Neighbours. His argument was that in the city 'our neighbours' are everywhere, providing goods and services, but usually remaining invisible and ignored by the middle classes. He lambasts his readers for thinking so little of the men who drive milk trains, work in signal boxes, or serve behind the scenes in hotels, and he urges them to consider how the conditions of working people could be improved. 'We know now, how they suffer who serve us. We realise how remote from our average standard of human existence and comfort they find it normal and natural to live'. ${ }^{78}$ What was needed, Holland believed, was a 'vision of the City ... by which all are linked up, by one life, in the common fellowship. Here is the instrument through which our will, and care, and love for our neighbour can take action ... The Town is the expression of our love for one another'. ${ }^{79}$ Thus the town's representatives must achieve what individual philanthropy no longer could. The municipal authorities must provide ample facilities - both sanitary and aesthetic - paid for from the rates, and Christians must become cheerful rate payers. Like Paton, Holland briefly nodded to Blake 'We begin to see how, through the Vision of the recovered City, we may yet aspire to build again Jerusalem in England's green and pleasant land'. ${ }^{80}$ Then he moved seamlessly into a redaction of Revelation 21:15-27, carefully editing the biblical text to remove descriptive details and references to the absence of the temple, and the presence of the Lamb of God. This produced five crisp sentences about a surveyor measuring a morally perfect city:

He that talked with me had a golden reed wherewith to measure the City. And he measured the wall thereof, according to the measure of a man, that is of the angel. And the City was pure gold, like unto clear glass. And there shall be no night there. And there shall in no wise enter therein anything that defileth or maketh a lie. ${ }^{81}$

\section{Conclusion}

I will not cease from mental strife,

Nor shall my sword sleep in my hand,

Till we have built Jerusalem

\footnotetext{
78 Holland, Our Neighbours, 74.

79 Holland, Our Neighbours, 74-5.

${ }^{80}$ Holland, Our Neighbours, 76.

${ }^{81}$ Holland, Our Neighbours, 77. Compare Rev 21: 15-27.
} 
In England's green and pleasant land.

It was with these words, the final stanza of William Blake's 'Jerusalem', that Ebenezer Howard began the first chapter of Tomorrow: A Peaceful Path to Real Reform. ${ }^{82}$ With every decade that passed since he first penned them, Blake's verses seemed to become ever more prescient. Even in the years before the poem was set as an anthem by Hubert Parry in 1916, it had clearly run deep into the English psyche, an important stratum in the multi-layered understanding of 'Jerusalem'. It is not clear whether J.B. Paton was aware that he was consciously borrowing from it, when he inserted the verb 'builded' into his exposition of Revelation 21, but Blake's poem had a powerful appeal, including to those like Holland who wanted to appeal to 'Jerusalem' language, both as an eschatological heavenly realm, and as a signifier for the creation of a better world in the here and now. It resonated strongly with those who believed that if life were to be worth living, it had to become 'green and pleasant'; the land clawed back from the encroachment of rows of tightly terraced housing and mills, even if they were now somewhat better managed, and less 'dark' and 'satanic' than they had been when the poem was written. Robert Vaughan had revealed a negative attitude to the countryside in the 1840s, but that was rapidly replaced by something more complicated. The countryside was simultaneously idealised and criticized, which created a fertile soil for the garden city doctrine. As Ebenezer Howard demonstrated visually in his 'Three Magnets' diagram, there was good and bad in town and country, but only an amalgam of the two could provide the best of both: 'beauty of nature; social opportunity ... low rents; high wages ... freedom; cooperation. ${ }^{83}$ As we have seen, his plan was baptised as the 'New Jerusalem' by clerical supporters such as Matheson. Howard's plan for building entirely new communities of thirty thousand people on undeveloped six thousand acre plots of agricultural land was obviously far more radical than the 'country in town' movement's scheme for window boxes in the city. 'Country in town' showed all the aesthetic yearning for beauty that was so characteristic of religious people at the fin de siècle - 'flower baskets showering down beauty' as Paton put it - but the garden city movement would be the direction taken by British town planners as the century turned.

\footnotetext{
82 E. Howard, Tomorrow: A Peaceful Path to Real Reform (London, 1898).

${ }^{83}$ Howard, Tomorrow, 8.
} 
Victorian preachers saw the city as the place where Christian virtues could be best expressed, sometimes in the form of challenges overcome. The relational theology of St Paul was a useful resource, but so were complex city metaphors derived from Revelation. The apocalyptic genre provided a useful vehicle for mixing ideas about what the city was in the past, with what it could be in the present and future. The city remained both a physical location and a metaphor for moral relationship. After his death, Holland wrote an appreciation of Paton, describing him trudging the streets of London, 'with his pockets bulging with schemes for bringing about the New Jerusalem'. ${ }^{84}$ The idea of the city providing the context for moral relationships between strangers was not of course new, and in Christian thought it continues to endure: the theologian Bruce Malina provided this definition of a city, in 2000: 'A city is a bounded, centralised set of social relationships concerned with effective collective action and expressed spatially in terms of architecture and the arrangement of places'. ${ }^{85}$ He was writing about the New Jerusalem in the Revelation of John, but he intended this definition to be applicable to all times and places. He does not mention size, or urban density.

By the end of the Victorian age, many of Britain's towns and cities had been built or rebuilt in the derivative Venetian gothic style that John Ruskin had been promoting since the 1850 s. ${ }^{86}$ It owed little to Pugin's original vision. The mass marketisation of gothic did not, of course, signify the return to a catholic faith. Britons, whether they were nonconformist worshippers, employees at the town hall, school or cemetery, or simply passengers alighting at the railway station, all began to encounter the style at first hand, and within a few decades, it had become the architecture that would signify the Victorian world. Had Pugin returned to consider 'the Same Town in 1900' he would have found parks and football pitches. He would have seen gothic architecture a-plenty, including for the lunatic asylums and chapels that he so despised. Moreover, inside the chapels and the training colleges, he would have encountered earnest nonconformists - or Free church people as they would now style themselves - engaged in plans for greening, growing and building their own versions of the 'new Jerusalem', fit for the twentieth century.

\footnotetext{
${ }^{84} \mathrm{~J}$. Scott Lidgett, My Guided Life (London, 1936), 102.

${ }^{85}$ Malina, New Jerusalem, 40.

${ }^{86}$ Hunt, Building Jerusalem, 86-95.
} 